\title{
Role of Mass Trapping in the Management of Leafminer (Tutaabsoluta) on Tomato in the Central Highlands of Kenya
}

\author{
Wafula G.O \\ Koppert Biological Systems (K) Ltd P.O \\ Kenya \\ Waceke J.W \\ Macharia C.M \\ Department of Agricultural Science and Technology, \\ Kenyatta University \\ Kenya
}

\begin{abstract}
Tomato plays a critical role in meeting domestic and nutritional food requirements, generation of income and creation of employment for both the rural and urban populations in Kenya. However, its production is threatened by the Tomato leafminer (Tuta absoluta). Tomato leaf miner (Tuta absoluta) is an important pest of tomato and can cause significant damage if not managed. Farmers mainly rely on chemical pesticides to manage this pest which has resulted in pest resistance and therefore the need for other alternatives that can be incorporated in an Integrated Pest Management (IPM). Integration of mass trapping in a management program could be one such alternative. Field experiments were set up to determine the effectiveness of various IPM packages for the management of Tuta absoluta in tomatoes compared to the farmer strategy of using chemical pesticide alone. The data collected was on Tuta absoluta incidence and yield. The integration of Mass Trapping, Azadirachtin, Bacillus thuringiensis and Chlorantraniliprole significantly reduced Tuta absoluta infestation under open field grown tomatoes. From this study, it can be concluded that mass trapping plays an important role in Integrated Pest Management (IPM) which could be the best approach for the management of Tuta absoluta in tomato.
\end{abstract}

Keywords: Tuta absoluta, Mass trapping, Integrated Pest Management

\section{Introduction}

Tomato is one of the most important vegetable, mainly grown by small scale farmers in most arable areas in Kenya. Tomatoes accounts for $14 \%$ of the total vegetable produce and $6.72 \%$ of the total horticultural crops (GoK, 2012). In Kenya, tomato plays a critical role in meeting domestic and nutritional food requirements, generation of income and creation of employment for both the rural and urban populations (Sigei et al., 2014). Despite its contribution to poverty alleviation and economic growth, tomato production is faced with a myriad of agronomic constraints which include insect pests (Tomato leafminer (Tuta absoluta), whiteflies (Bemisia tabaci), thrips (Frankliniella occidentalis), African bollworm (Helicoverpa amigera) among others), nematode pest (Meloidogynespp), diseases (Bacterial wilt (Ralstonia solanacearum), early blight (Alternaria solani), late blight (Phytophthora infestans), fusarium wilt (Fusarium oxysporum f.sp. lycopersici) among others), viruses and poor crop management. Among insect pests, the leaf miner is the most serious pest which was first identified in Kenya in early 2014 (Preliminary Report IPPC, 2014). If timely control and management measures are not taken, the pest can cause up to 100\% crop loss in tomatoes (IRAC, 2014). The pest has high reproductive capacity and short generation cycle that is temperature dependent. In Kenya, with all year round growing conditions, the moth will not go into diapause hence will probably have 12 overlapping generations in a year (KARI, 2014). In Kenya, a generation may take 3 to 5 weeks to complete, depending on seasonal temperature and whether the tomatoes are field grown or indoors. Though tomato is the primary host, pests also attacks other crop plants of the nightshade family, including potato, pepino and tobacco. Further, many solanaceous weeds act as alternate hosts, this includes Datura stramonium, Solanum nigrum and Lyciumchilense (IPPC, 2014). 
The other insect pests (white flies and thrips) play an important role directly and indirectly as they serve as vectors of economically important viruses Management of Tuta absoluta has exclusively depended on chemical control regardless of limited number of effective insecticides available. This situation usually leads to an increase in the frequency of use, and thus increased selection pressure for resistance (IRAC, 2014). Therefore, pesticide resistance and lack of awareness of growers of its potential economic impact are two important contributing factors leading to high crop loss in central Highlands of Kenya. Therefore, in selection of management strategies there is need to promote resistance monitoring and advance the development and use of resistance management strategies, in combination with other strategies within the context of Integrated Pest Management strategies.

\section{General objective}

To improve tomato production through the development and validation of Integrated Pest Management strategies for Tomato leafminer (Tuta absoluta) within smallholder farms in Central Highlands of Kenya.

Specific objective: To determine the efficacy of IPM packages in the management of Tomato leaf miner (Tuta absoluta)

\section{Materials and Methods}

Experimental site-

The field experiments were carried out in farmer's fields in Mwea, Kirinyaga County. Mwea falls is in a lower midland zone 4 (LM4) at an altitude of $1,050 \mathrm{~m}$ above sea level. The area is on Latitude: $0^{\circ} 45^{\prime}\left(0.75^{\circ}\right)$ south and Longitude: $37^{\circ} 29^{\prime}\left(37.4833^{\circ}\right)$ east. It is under a semi-arid area with soils classified as nitosols. The area experiences a bimodal rainfall with an average rainfall of about $850 \mathrm{~mm}$. The average temperature about is $22^{\circ} \mathrm{C}$ which makes the area conducive for plant growth throughout the year. Two on-farm experiments for management of Tutaabsolutawere set up on farmers' fields in Mwea and Kagio localities in Kirinyaga County in two seasons (March - July 2016) and September 2016- January 2017. Two sites were selected; one in Mwea and one in Kagio locations.

Treatments and treatment application schedule

Table 1: Treatment application schedule for Tutaabsoluta management plots

\begin{tabular}{|c|c|c|c|}
\hline Treatment & Application Rate & Start of Application & $\begin{array}{l}\# \text { of } \\
\text { Applications }\end{array}$ \\
\hline Control & - & - & - \\
\hline $\begin{array}{l}\text { Chlorantraniliprole } \\
\text { (Ch) }\end{array}$ & $\begin{array}{l}\text { Chlorantraniliprole: } \\
5 \mathrm{ml} / 201\end{array}$ & $\begin{array}{l}\text { Sprayed } 4 \text { weeks after } \\
\text { transplanting }\end{array}$ & 3 \\
\hline Mass trapping (MT) & $\begin{array}{l}20 \quad \text { water } \\
\text { traps+pheromone/acre }\end{array}$ & $\begin{array}{l}\text { Placed } 2 \text { weeks after } \\
\text { transplanting }\end{array}$ & 6 \\
\hline Azadirachtin (Aza) & Azadirachtin: $3 \mathrm{ml} / 1$ & $\begin{array}{l}\text { Drenched } 2 \text { weeks after } \\
\text { transplanting }\end{array}$ & 3 \\
\hline B. thuringiensis $(\mathrm{Bt})$ & $\begin{array}{l}\text { Bacillus thuringiensis: } \\
10 \mathrm{~g} / 201\end{array}$ & $\begin{array}{l}\text { Sprayed } 4 \text { weeks after } \\
\text { transplanting }\end{array}$ & 3 \\
\hline $\mathrm{MT}+\mathrm{Aza}$ & As above respectively & As above respectively & As above respectively \\
\hline $\mathrm{MT}+\mathrm{Bt}$ & As above respectively & As above respectively & As above respectively \\
\hline MT+ Aza & As above respectively & As above respectively & As above respectively \\
\hline $\mathrm{MT}+\mathrm{Aza}+\mathrm{Bt}$ & As above respectively & As above respectively & $\begin{array}{l}\text { As above respectively on } \\
\text { alternate weeks }\end{array}$ \\
\hline $\mathrm{MT}+\mathrm{Aza}+\mathrm{Bt}+\mathrm{Ch}$ & As above respectively & As above respectively & $\begin{array}{l}\text { As above respectively on } \\
\text { alternate weeks }\end{array}$ \\
\hline
\end{tabular}

Experimental design 
Both experiments were laid out in a Randomized Complete Block Design (RCBD) with three replications during the month of March to July 2016 and repeated in the month of September 2016 to January 2017. Plots measuring $25 \mathrm{~m}^{2}$ were used as experimental plots.

\section{Crop and Agronomy}

Tomato seedlings of variety Rambo F1 were transplanted at a spacing of $60 \mathrm{~cm}$ by $45 \mathrm{~cm}$. Standard tomato agronomic practices i.e. pest and disease management, fertilizer application and weed control were applied uniformly across the treatments in both experiments.

\section{Data collection}

Assessment of Tomato yield

Mature fruits were harvested from physiological maturity and continued up to final stage of the crop. The total weight per harvest per plot was recorded for each harvest. Un-marketable fruits especially very small (fruits weighing less than $50 \mathrm{~g}$ ), deformed or those damaged by pests and diseases were sorted out and weighed. Marketable yield was determined by getting the difference between total yield and un-marketable yield. Using the unit area per plot, the yield per plot was extrapolated to give yield in kilograms per hectare.

\section{Assessment of Tuta absoluta incidence}

Tomato leaf miner incidence was determined by counting the number of infested plants per treatment and recording it as a percentage of the total number of plants per plot.

Data Analysis

All data collected was subjected to an Analysis of Variance (ANOVA) using GenStat statistical package $15^{\text {th }}$ edition. Treatment means were separated by Fischer Protected LSD at 5\% probability level.

\section{Results}

Tutaabsoluta incidence

In Kagio, Tutaabsolutaincidence at 12 weeks after transplanting was higher in the order $\mathrm{MT}+\mathrm{Neem}+\mathrm{Bt}+$ Coragen $<\mathrm{FP}<\mathrm{MT}+\mathrm{Neem}+\mathrm{BT}<\mathrm{MT}+\mathrm{Bt}<\mathrm{Neem}<\mathrm{Bt}<\mathrm{MT}<\mathrm{MT}+\mathrm{Neem}<$ Control during the first season. In the second season, Tutaabsolutaincidence at 12 weeks after transplanting was higher in the order $\mathrm{MT}+\mathrm{Neem}+\mathrm{Bt}+$ Coragen $<\mathrm{MT}+\mathrm{Neem}<\mathrm{MT}<\mathrm{MT}+$ Coragen $<\mathrm{Bt}<\mathrm{MT}+\mathrm{Neem}+\mathrm{Bt}<\mathrm{Neem}<\mathrm{MT}+\mathrm{Bt}<\mathrm{FP}<\mathrm{Control}$

(Figure 2). In Mwea, Tutaabsoluta incidence at week 12 from transplanting was higher in the order Neem $<\mathrm{MT}+\mathrm{Neem}+\mathrm{BT}+$ Coragen $<\mathrm{MT}+\mathrm{Neem}<\mathrm{MT}+\mathrm{Neem}<\mathrm{MT}+\mathrm{BT}>\mathrm{Bt}<\mathrm{MT}+\mathrm{Neem}+\mathrm{Bt}<\mathrm{MT}<\mathrm{FP}<\mathrm{Control}$ in the first season.In Mwea, Tutaabsolutaincidence at 12 weeks after transplanting was higher in the order $\mathrm{MT}<\mathrm{Neem}<\mathrm{MT}+\mathrm{Bt}<\mathrm{MT}+\mathrm{Neem}+\mathrm{Bt}+$ Coragen $<\mathrm{MT}+$ Coragen $<\mathrm{FP}<\mathrm{MT}+\mathrm{Neem}<\mathrm{Bt}<$ Control (Figure 3).

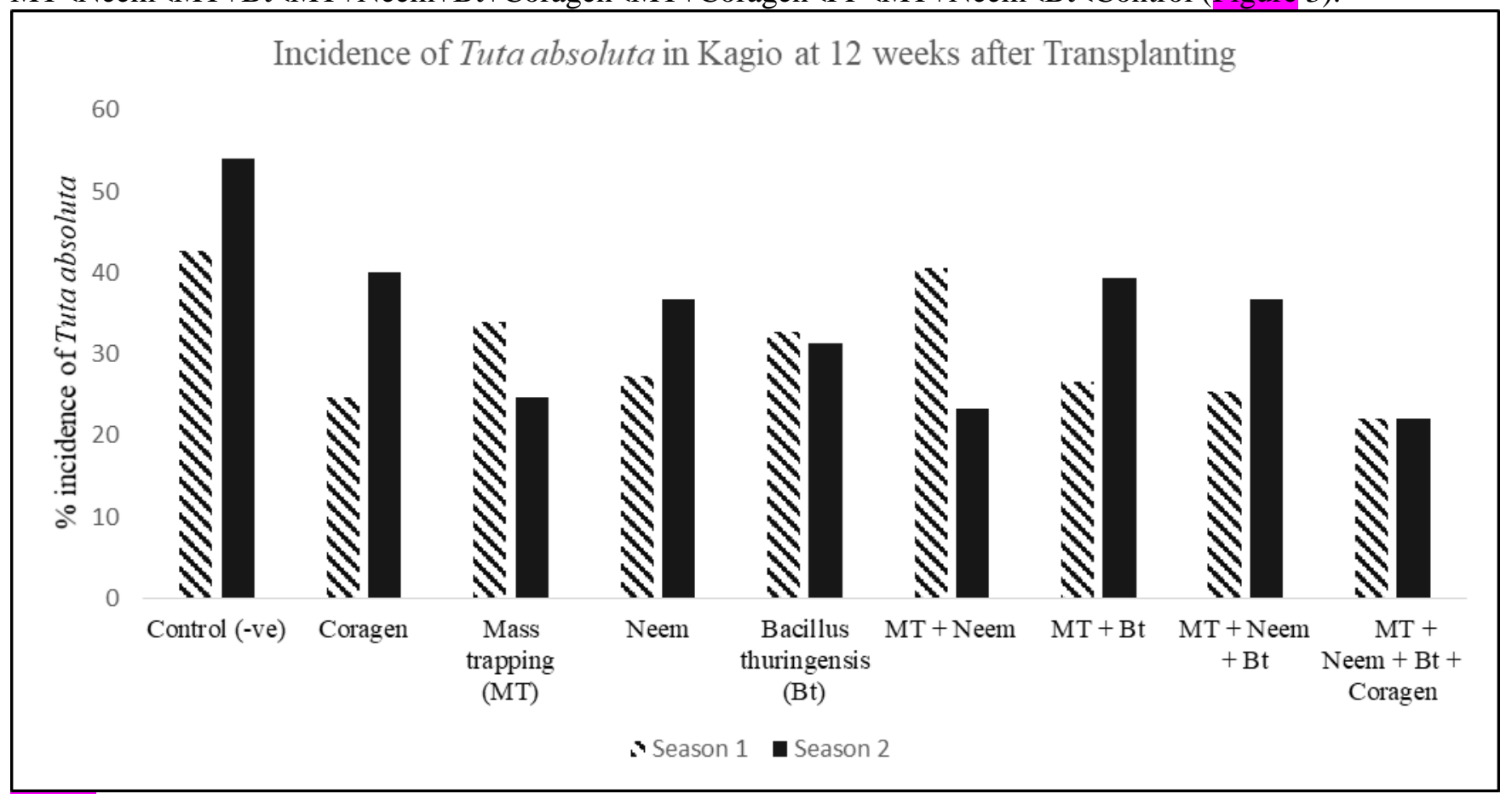

Figure 2: Mean T. absoluta incidence at week 12 in Kagio for season one and season two in each treatments 


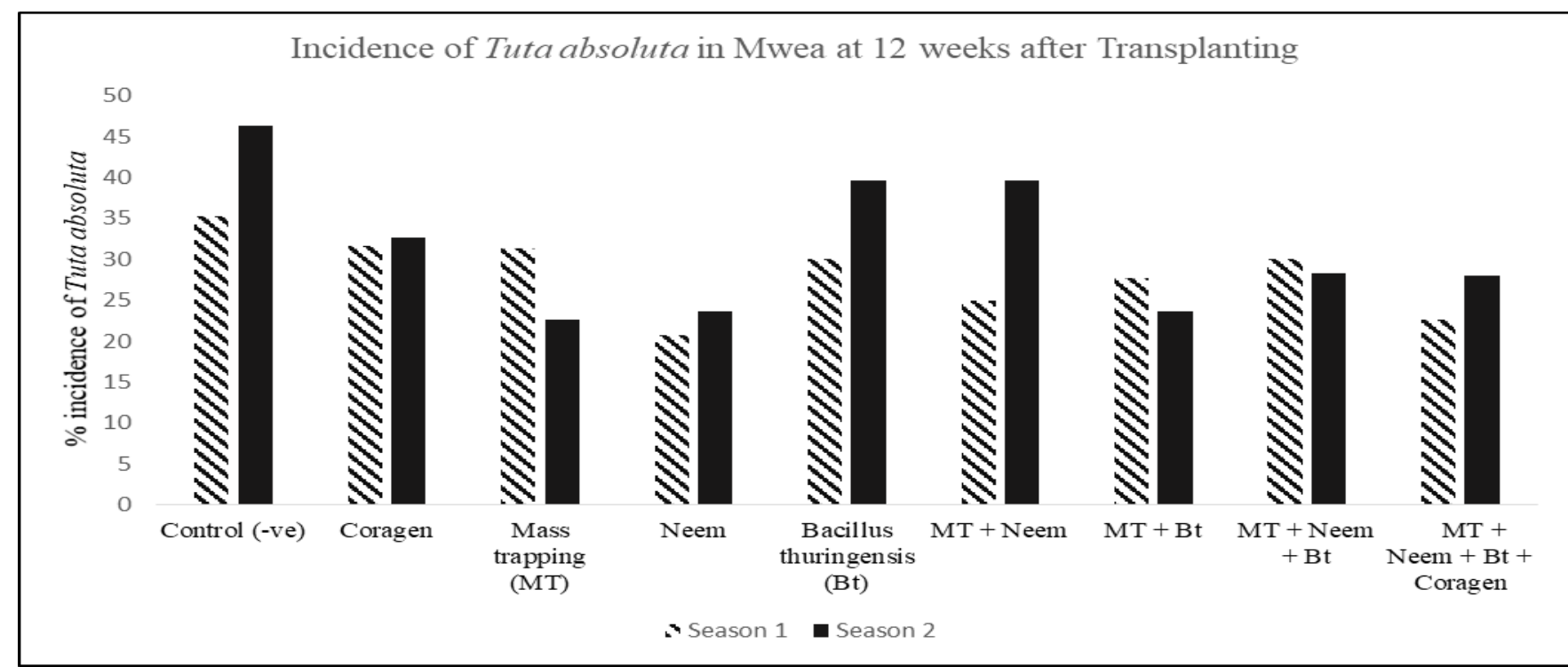

Figure 3: Mean T. aboluta incidence at week 12 in Kagio for season one and season two in each treatments

\section{Tomato Yield}

In Mwea, Control recorded a significantly lower marketable and total yield relative to other treatments (Table 2). The highest marketable yield was reported in the Mass Trapping + Bt treated plots, though not significantly different from the other treatments apart from Control, Neem alone and Mass Trapping alone in the first season.In the second season, there was no significant difference among treatments on marketable and total yield of tomato(Table 3).In Kagio, Application of Mass Trapping + Azadirachtin + B. thuringiensis +Chlorantraniliprole significantly $(\mathrm{P}<0.05)$ increased the marketable and total yield of tomato in the first season (Table 2$)$. In the second season, Mass Trapping + Bt had significantly higher marketable and total yield relative to other treatments (Table 3). Control maintained the lowest yield in both marketable and total yield.

Table 2:Mean ${ }^{\dagger}$ marketable and total yield $(\mathrm{kg} / \mathrm{ha})$ of tomatoes grown under different treatment combinations in Mwea and Kagio experimental sites; 90 days after transplanting. Season 1

\begin{tabular}{lllll}
\hline & Mwea & & \multicolumn{2}{l}{ Kagio } \\
\cline { 2 - 5 } & $\begin{array}{l}\text { Marketable } \\
\text { Yield } \\
(\mathrm{kg} / \mathrm{ha})\end{array}$ & $\begin{array}{l}\text { Total } \\
\text { Yield } \\
(\mathrm{kg} / \mathrm{ha})\end{array}$ & $\begin{array}{l}\text { Marketabl } \\
\mathrm{e} \text { Yield } \\
(\mathrm{kg} / \mathrm{ha})\end{array}$ & $\begin{array}{l}\text { Total } \\
\text { Yield } \\
(\mathrm{kg} / \mathrm{ha})\end{array}$ \\
\hline Treatment & $47188 \mathrm{a}$ & $55000 \mathrm{a}$ & $43750 \mathrm{a}$ & $50417 \mathrm{a}$ \\
Control & $64063 \mathrm{c}$ & $71250 \mathrm{~d}$ & $50625 \mathrm{~cd}$ & $56667 \mathrm{c}$ \\
(Ch) & & & & \\
Mass trapping (MT) & $58438 \mathrm{~b}$ & $65000 \mathrm{bc}$ & $46875 \mathrm{abc}$ & $52917 \mathrm{ab}$ \\
Azadirachtin (Aza) & $55625 \mathrm{~b}$ & $62292 \mathrm{~b}$ & $48333 \mathrm{bc}$ & $54375 \mathrm{bc}$ \\
B. thuringiensis (Bt) & $64063 \mathrm{c}$ & $71563 \mathrm{~d}$ & $45000 \mathrm{ab}$ & $53438 \mathrm{ab}$ \\
& & & & $\mathrm{c}$ \\
MT+ Aza & $63958 \mathrm{c}$ & $71250 \mathrm{~d}$ & $45938 \mathrm{ab}$ & $51875 \mathrm{ab}$ \\
MT+ Bt & $65208 \mathrm{c}$ & $68750 \mathrm{~cd}$ & $53750 \mathrm{~d}$ & $61875 \mathrm{~d}$ \\
MT+ Aza & $63125 \mathrm{c}$ & $69375 \mathrm{~cd}$ & $45208 \mathrm{ab}$ & $50625 \mathrm{a}$ \\
MT+ Aza + Bt & $63458 \mathrm{c}$ & $70333 \mathrm{~d}$ & $45625 \mathrm{ab}$ & $53333 \mathrm{ab}$ \\
& & & & $\mathrm{c}$ \\
\hline Mean & $\mathbf{6 0 5 7 0}$ & $\mathbf{6 7 2 0 1}$ & $\mathbf{4 7 2 3 4}$ & $\mathbf{5 3 9 4 7}$ \\
LSD & $\mathbf{4 4 0 2}$ & $\mathbf{4 4 7 5}$ & $\mathbf{4 2 7 8}$ & $\mathbf{3 4 1 2}$ \\
P-value & $<\mathbf{0 . 0 0 1}$ & $<\mathbf{0 . 0 0 1}$ & $\mathbf{0 . 0 0 3}$ & $<\mathbf{0 . 0 0 1}$ \\
\hline
\end{tabular}

${ }^{\dagger}$ Mean for three replications.

$*$ Means with different letters are significantly different at $p=0.05$ according to Fischer Protected LSD (Least Significant Difference). 
Table 3: Effect of different treatment combinations on T. absolutaincidence and yield of tomato in Mwea and Kagio sites; 90 days after transplanting. Season 2

\begin{tabular}{lllll}
\hline & \multicolumn{3}{l}{ MweaKagio } & \\
\cline { 2 - 5 } & $\begin{array}{l}\text { Marketable } \\
\text { Yield } \\
(\mathrm{kg} / \mathrm{ha})\end{array}$ & $\begin{array}{l}\text { Total } \\
\text { Yield } \\
\text { Treatment }\end{array}$ & $\begin{array}{l}\text { Marketabl } \\
\mathrm{e} \text { Yield } \\
(\mathrm{kg} / \mathrm{ha})\end{array}$ & $\begin{array}{l}\text { Total Yield } \\
(\mathrm{kg} / \mathrm{ha})\end{array}$ \\
\hline Control & 44292 & 50625 & $39354 \mathrm{a}$ & $45625 \mathrm{a}$ \\
Chlorantraniliprole & 46042 & 51875 & $46250 \mathrm{bc}$ & $51875 \mathrm{bc}$ \\
(Ch) & & & & \\
Mass trapping (MT) & 46563 & 53333 & $50000 \mathrm{~cd}$ & $55938 \mathrm{~cd}$ \\
Azadirachtin (Aza) & 45000 & 52813 & $45313 \mathrm{bc}$ & $52188 \mathrm{bc}$ \\
B. thuringiensis $(\mathrm{Bt})$ & 48958 & 55000 & $46250 \mathrm{bc}$ & $52500 \mathrm{bcd}$ \\
MT+ Aza & 45417 & 51667 & $42708 \mathrm{ab}$ & $48542 \mathrm{ab}$ \\
MT+ Bt & 49375 & 57708 & $44375 \mathrm{~b}$ & $50625 \mathrm{ab}$ \\
MT+ Aza & 46875 & 55625 & $51250 \mathrm{de}$ & $57500 \mathrm{de}$ \\
MT+ Aza + Bt & 45000 & 51563 & $55938 \mathrm{ef}$ & $61875 \mathrm{ef}$ \\
MT+ Aza +Bt + Ch & 44688 & 52500 & $57813 \mathrm{f}$ & $65938 \mathrm{f}$ \\
\hline Mean & $\mathbf{4 6 2 2 1}$ & $\mathbf{5 3 2 7 1}$ & $\mathbf{4 7 9 2 5}$ & $\mathbf{5 4 2 6 0}$ \\
LSD & $\mathbf{8 6 6 7}$ & $\mathbf{8 6 3 7}$ & $\mathbf{4 9 2 4}$ & $\mathbf{5 0 7 5}$ \\
P-value & $\mathbf{N S}$ & $\mathbf{N S}$ & $<\mathbf{0 . 0 0 1}$ & $<\mathbf{0 . 0 0 1}$ \\
\hline
\end{tabular}

Means with different letters are significantly different at $p=0.05$ according to Fischer Protected LSD (Least Significant Difference).

\section{Discussion}

Mass trapping either singly or in combination with bio-pesticides or chemical pesticides significantly reduced the incidence of Tuta absoluta. This is corroborates with the results of Emre and Orkun, (2016) who reported mass trapping as being effective in reducing low-density populations of the tomato leaf miner. In combination with other pesticides (Bacillus thuringiensis, Azadirachtin and Chlorantraniliprole), mass trapping performed better with regards reducing number of plants damaged by Tuta absoluta. This can be attributed to the fact that the pesticides targeted the larval stages of Tuta absoluta hence minimizing the damaging effect of the insect pest, whereas mass trapping slowed down both establishment and spread Tutaabsoluta(Emre and Orkun, 2016). Since the water trap and the pheromone were set up 2 weeks after transplanting i.e. when the pest population was low, typically this had the potential of manipulating the Allee effects to the detriment of the invasive pest. A good number of moths (males) were removed from the population through mass trapping decreasing the availability of mates, consequently, leading to a population decline (El-Sayed et al., 2006; Tobin et al., 2011)

The study has reported that Tuta absolutaincidence did not significantly differ among the treatments in both seasons. This can probably be attributed to the pathenogenetic nature of Tuta absoluta. It has recently been confirmed that the pest is able to reproduce without mating, a trait that has serious implications on the sex pheromone management strategy (Silva, 2008; Caparros Megido et al., 2012). However, this strengthens the emphasis on an integrated approach in management of Tuta absoluta, especially with efficacy of most chemical pesticides being poor due to the endophytic habit of the larvae which is protected in the leaf messophyl or inside fruit (Cocco et al., 2013) and pest resistance against a number of applied insecticides (Siqueira et al., 2000a; Siqueira et al., 2000b; Siqueira et al., 2001; Lietti et al., 2005; Silva et al., 2011; Reyes et al., 2012)

Across the seasons, control maintained a significantly lower yield in the Tuta absoluta management sites. However, among the treated plots, mixed results were reported with the treatments with highest yield varying across the sites and seasons. Probably this suggests that IPM recommendations might be site specific and dependent on the pest population. Studies on the application of the mating disruption technique against $T$. absoluta in open field tomato crops showed mixed results on quality of produce (MichereffFilho et al., 2000; Vacas et al., 2011; Cocco et al., 2013). The pheromone treatment did not significantly reduce the damage to leaflets and fruits, probably due to the synthetic pheromone's composition and dose, the high pest population density, or the migration of mated females to the treated area. 


\section{Conclusion}

Tuta absolutaincidence was lower under Mass Trapping with much lower incidence levels being recorded when further applications of azadirachtin, Bacillus thuringiensis and chlorantraniliprole was done. This reaffirmed the potential role of mass trapping in an Integrated Pest Management (IPM) strategy for Tuta absoluta in tomato production. Generally, our results demonstrate mass trapping in an Integrated Pest Management as a viable option for managing of Tuta absoluta.

\section{Acknowledgements}

This research project was carried out with financial support from the Food and Business Applied Research Fund (ARF) under the Netherlands Organization for Scientific Research (NWO) WOTRO Science for Global Development.

\section{References}

Aksoy, E. \& Kovanci, O.B. (2016). Mass trapping low-density populations of Tuta absoluta with various types of traps in fieldgrown tomatoes. Journal of Plant Diseases and Protection, Volume 123, Issue 2, pp 51-57.

Caparros Megido R, H. E. (2012). First evidence of deuterotokous parthenogenesis in the tomato leafminer, Tuta absoluta (Meyrick) (Lepidoptera:Gelechiidae). Journal of Pest Science, 85:409-412.

Cocco A., Deliperi S. \& Delrio G. (2013). Control of Tuta absoluta (Meyrick) (Lep., Gelechiidae) in greenhouse tomato crops using the mating disruption technique. Journal of Applied Entomology, 137(1-2) 16-28.

El-Aassar M.R. a, Soliman. M.H.A a, Abd Elaal A.A., b. (2015). Efficiency of sex pheromone traps and some bio and chemical insecticides against tomato borer larvae, Tuta absoluta (Meyrick) and estimate the damages of leaves and fruit tomato plant. Annals of Agricultural Sciences, Volume 60, Issue 1, Pages 153-156.

El-Sayed AM, Suckling DM, Wearing CH, Byers JA . (2006). Potential of mass trapping for long-term pest management and eradication of invasive species. Journal of Economic Entomology , 99:1550-1564.

Emre Aksoy and Orkun Baris Kovanci. (2015). Mass trapping low-density populations of Tuta absoluta with various types of traps in field-grown tomatoes. J. Plant Dis Prot. , DOI 10.1007/s41348-016-0003-6.

Government of Kenya. (2012). National Horticulture Policy. Ministry of Agriculture, Kilimo House, Nairobi. www.kilimo.go.ke. Accessed on 7th April 2016.

Insect Resistance Action Committee (IRAC). (2014). Mode of Action Classification Scheme (Version 7.3.1). http://www.iraconline.org.

IPPC. (2014). Preliminary report.

Kenya Agricultural and Livestock Research Organization (KALRO). (2014). Annual report.

Lietti M.M.M., Botto E. \& Alzogaray R.A. (2005). Insecticide resistance in Argentine populations of Tuta absoluta (Meyrick) (Lepidoptera: Gelechiidae). Neotropical Entomology, 34(1), 113-119.

Michereff Filhoa, Evaldo F. Vilelaa, Gulab N. Jhamb, Athula . (2000). Initial studies of mating disruption of the tomato moth, Tuta absoluta (Lep., Gelechiidae) using synthetic sex pheromone. Journal of the Brazilian Chemical Society, 11(6), 621-628.

Reyes M, Rocha K, Alarcon L, Siefwart M, Sauphanor B. (2012). Metabolic mechanisms involved in the resistance of field populations of Tuta absoluta (Meyrick) (Lep., Gelechiidae) to spinosad . Pesticide Biochemistry and Physiology, 102(1), 45-50.

Sigei, K. G., Ngeno, K. H., Kibe, M. A., Mwangi, M. M. and Mutai, C. M. (2014). Challenges and strategies to improve tomato competitiveness along tomato value chain in Kenya. International Journal of Business and Management, 9 (9): 230 - 245.

Silva GA1, Picanço MC, Bacci L, Crespo AL, Rosado JF, Guedes RN. (2011). Control failure likelihood and spatial dependence of insecticide resistance in the tomato pinworm, Tuta absoluta. Pest Management Science, 67(8), 913-920.

Siqueira H.A., Guedes R.N. \& Picanço M.C. (2000). nsecticide resistance in populations of Tuta absoluta (Lep., Gelechiidae). Agriculture for Entomology, 2(2) 147-153.

Siqueira H.A., Guedes R.N. \& Picanco M.C. (2000). Cartap resistance and synergism in populations of Tuta absoluta (Lep., Gelechiidae). J. Appl. Entomol., . Journal of Applied Entomology, 124(5-6), 233-238.

Siqueira H.A., Guedes R.N., Fragoso D.B. \& Magalhaes L.C. (2010). Abamectin resistance and synergism in Brazilian populations of Tuta absoluta (Meyrick) (Lepidoptera: Gelechiidae). International Journal of Pest Management, 47(4), 247-251.

Tobin PC, Berek L, Liebhold AM . (2011). Exploiting Allee effects for managing biological invasions. Ecology Letters,, 14: 615624.

Vacas S., Alfaro C., Primo J. \& Navarro-Llopis V. (2011). Studies on the development of a mating disruption system to control the tomato leafminer, Tuta absoluta Povolny (Lepidoptera: Gelechiidae). Pest Management Science , 67(11), 1473-1480. 